\title{
Ingestion and incorporation of coral mucus aggregates by a gorgonian soft coral
}

\author{
Mary Alice Coffroth \\ Rosenstiel School of Marine and Atmospheric Science, University of Miami, 4600 Rickenbacker Causeway, \\ Miami, Florida 33149, USA
}

\begin{abstract}
Mucus produced by reef corals is a potential energy source for reef organisms. Ingestion and incorporation of mucus aggregates by the gorgonian soft coral Pseudoplexaura porosa was examined using stain and isotope techniques. $P$. porosa was fed mucus particles stained with neutral red. Virtually all ingested food was cleared from the gut in 3 to $4 \mathrm{~h}$. Gorgonians fed ${ }^{14} \mathrm{C}$-labelled mucus for $10 \mathrm{~min}$, ingested a mean of $0.91 \mu \mathrm{g}$ dry weight mucus $\mathrm{mg}^{-1}$ gorgonian, and incorporated $22 \%$ of the ingested mucus. The amount of mucus incorporated in these experiments is sufficient to meet the energy needs of $P$. porosa.
\end{abstract}

\section{INTRODUCTION}

Mucus aggregates, commonly observed in reef waters, represent a potential energy source to reef particulate feeders. Over reefs, corals are major mucus producers, contributing 51 to $480 \mathrm{mg} \mathrm{m}^{-2} \mathrm{~d}^{-1}$ (Eilat: Richman et al., 1975; Eniwetak: Johannes, 1967). Mucus released into the water quickly breaks up into small particles that form matrices of detrital material and microorganisms, providing nutritious food particles (Marshall, 1969; Ducklow and Mitchell, 1979). In addition to this enrichment, mucus itself is a nutritionally valuable food source, containing wax esters, triglycerides, fatty acids and other energy-rich compounds (Coles and Strathmann, 1973; Benson and Muscatine, 1974; Ducklow and Mitchell, 1979). Mucus aggregates, which have a caloric value between 3.95 and $5.2 \mathrm{cal}$ $\mathrm{mg}^{-1}$ ash-free dry weight (AFDW), contain more organic matter than other particulate material in the surrounding water and are also nitrogen enriched when compared with recently released mucus or other microscopic particulate organic matter (Coles and Strathmann, 1973; Rublee et al., 1980).

Fish, crabs, shrimp, bivalves, and zooplankton ingest mucus aggregates (Goreau et al., 1970; Benson and Muscatine, 1974; Richman et al., 1975; Daumas and Thomassin, 1977; Gottfried and Roman, 1983). Artemia salina and the mysid Mysidiurn integrum have been maintained on diets of only mucus for up to $2 \mathrm{mo}$ (Johannes, 1967; Gottfried and Roman, 1983). How- ever, the ingestion of these aggregates has only been quantified in zooplankton studies (Richman et al., 1975; Gottfried and Roman, 1983). Although particulate feeders abound on the reef, few studies have examined feeding using a natural food particle, such as mucus. For example, gorgonian soft corals act as particulate suspension feeders, in addition to relying on their symbiotic zooxanthellae for nutrition (Roushdy and Hansen, 1961; Lasker, 1981). Due to a low number of nematocysts (Mariscal and Bigger, 1977) and reduced ability to capture motile zooplankters (Kinzie, 1970; Lasker, 1981), particle feeding may be significant as an alternate food-gathering mechanism for gorgonians. However, particulate feeding in gorgonians has not been examined utilizing natural food particles. This study demonstrates that mucus aggregates, a common food resource in the reef environment, can be utilized by the gorgonian Pseudoplexaura porosa.

\section{MATERIALS AND METHODS}

Branch tips from Pseudoplexaura porosa, a large arborescent gorgonian common to patch-reef and back-reef environments, were used in feeding experiments conducted at Bache Shoals in the Florida Keys (USA) and Carrie Bow Cay, Belize. Experiments were conducted at a depth of $4 \mathrm{~m}$ using in situ chambers with thin, flexible polyethylene walls (Fig. 1). The flexible walls transmitted wave energy to the enclosed 


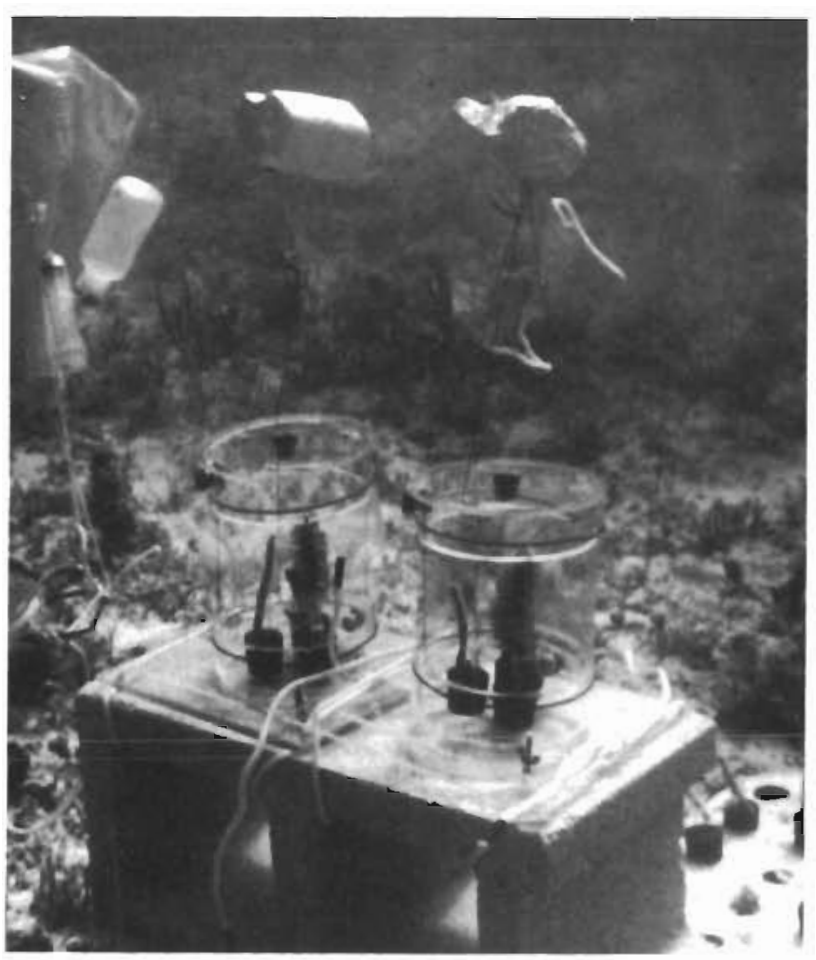

Fig. 1. Flexible-walled in situ chambers used in feeding experiments

space, thus simulating natural conditions (Gust, 1977; Lasker, 1981) and also keeping food particles suspended. The cylindrical $1 \mathrm{l}$ chambers were constructed with a plexiglass base and top and were held up by a styrofoam float.

Prior to experimentation, branch tips (approximately $6 \mathrm{~cm}$ in length) were clipped from a colony of Pseudoplexaura porosa, attached to glass rods with cable ties, placed on the chamber base and allowed to acclimate at least $2 \mathrm{~h}$. Behavior of branch tips treated in this manner is comparable to that of the whole colony (Lasker, 1981; Lasker et al., 1983; own obs.). All of the branch tips used in a single experiment were collected from the same colony. Four branch tips were used in each experimental chamber. In the ingestion and incorporation experiments, 2 dried branch tips were used as non-feeding controls to account for any adsorption of radioactive label. A comparison between adsorption of label in live, non-feeding branch tips (polyps retracted) and dead (dried) branch tips showed no significant difference between control types (1-way ANOVA; $\mathrm{P}>0.05, \mathrm{df}=5.7, \mathrm{f}=1.715)$. Dried branch tips were used to preclude incomplete polyp retraction or polyp expansion which is always a possibility in live, non-feeding controls.

\section{Mucus source}

Mucus for the experiments was obtained from colonies of the finger coral Porites divaricata maintained in an aquarium with a continuous flow of seawater. $P$. divaricata, like other Porites species, secretes mucus as a sheet that covers the coral surface and this sheet is eventually shed into the water column (Lewis, 1973; own obs.). Formation of these mucus sheets occurs in laboratory aquaria as well as in the field, and sheets that formed in the aquarium have the same appearance as those sheets observed in the field (Lewis, 1973; own obs.).

Mucus sheets were collected from colonies of Porites divaricata with a pipet, ground into particles and labelled as indicated below. Labelled mucus particles were then washed, resuspended in filtered seawater (FSW) and subsamples taken for mucus concentration, and where applicable, specific activity determinations. Equal alliquots of the labelled mucus suspension were injected into the in situ chambers.

\section{Digestion time course}

Digestion of mucus was followed using mucus stained overnight with a $0.05 \%$ solution of neutral red in an acidified seawater solution ( $\mathrm{pH} 6.5)$. Labelled mucus was injected into each of 6 chambers. After 15 min all chamber tops were removed and 4 of the 24 branch tips were randomly selected, collected, and preserved. The remaining branch tips were left in situ and at $0.5,1.0,2.0,3.0$, and $4.0 \mathrm{~h}, 4$ additional branch tips were collected and fixed. Twenty randomly selected polyps were dissected from each branch tip and examined at $80 \times$ for the presence of stained mucus. To enhance the color of the neutral red stain, a drop of concentrated acetic acid was added to the slide (Fleming and Cloughlan, 1978).

\section{Ingestion and incorporation experiments}

Because corals readily assimilate glucose and zooxanthellae take up and use acetate in the synthesis of fatty acids, ${ }^{14} \mathrm{C}$-glucose and ${ }^{14} \mathrm{C}$-acetate were used to obtain radioactive-mucus (Stephens, 1962; Lewis and Smith, 1971; Patton et al., 1983). Porites divaricata colonies were incubated under constant illumination in $500 \mathrm{ml}$ of aerated FSW with isotopic glucose, $\mathrm{D}\left[{ }^{14} \mathrm{C}(\mathrm{U})\right], \quad\left(0.06 \mu \mathrm{Ci} \mathrm{ml} \mathrm{m}^{-1}\right)$ and ${ }^{14} \mathrm{C}$-acetate $(0.16 \mu \mathrm{Ci}$ $\mathrm{ml}^{-1}$ ) to produce radioactively-labelled mucus.

In the incorporation experiments, labelled mucus was injected into the chambers, with a final mucus concentration of $14.6 \mathrm{mg}$ dry weight (dw) mucus $1^{-1}$. 
After a feeding period of $10 \mathrm{~min}$, the chambers were removed and 1 dead control branch tip and 1 live branch tip were collected from each chamber and

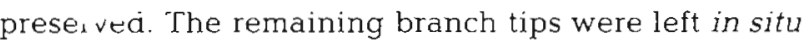
for $4 \mathrm{~h}$ to clear the polyp gut of radioactive food. These branch tips were then collected and preserved. Branch tips from this experiment were freezed-dried and divided into $2 \mathrm{~cm}$ segments. Each $2 \mathrm{~cm}$ section was ground to a fine powder. Replicate $10 \mathrm{mg}$ subsamples of the top and middle segments were digested with $0.5 \mathrm{ml}$ of a tissue solubilizer (Protosol, New England Nuclear) for $20 \mathrm{~h}$ at $55^{\circ} \mathrm{C}$. Tris buffer $(0.5 \mathrm{ml}$ of $1 \mathrm{M}$ Tris [hydroxymethyl] aminomethane and hydrochloride [Trizma-7.2, Sigma]) was added to lower $\mathrm{pH}$, thus reducing chemiluminescence, and $8.0 \mathrm{ml}$ of scintillation cocktail (Aquasol, New England Nuclear) was then added to each vial. The samples were counted twice with a Nuclear Chicago Model 6844 Mark II liquid scintillation counter and counts corrected for quenching

Ingestion of coral mucus particles was followed in a second experiment by labelling the bacteria attached to mucus particles. The mucus particles were incubated with ${ }^{3} \mathrm{H}$-adenine $\left(100 \mu \mathrm{Ci} \mathrm{ml}^{-1}\right)$ in FSW for $24 \mathrm{~h}$. After incubation the mucus particles with attached, labelled bacteria were washed several times with FSW to remove any unattached bacteria and free isotope. This technique provided radioactively-labelled mucus in a short time, avoided a 2-step isotope transfer from zooxanthellae to corals and yielded higher specific activities with a smaller volume of isotope.

These experiments were conducted in a manner similar to the incorporation experiment, except that all branch tips were collected after the 10 min feeding period. A mucus concentration of $9.2 \mathrm{mg} \mathrm{dw}$ mucus $\mathrm{l}^{-1}$ was used and the branch tips were preserved, processed, and counted as previously described.

\section{RESULTS}

Gorgonians ingested mucus particles labelled with dye in the digestion time course experiment. After the 15 min feeding period, $30 \%$ of the polyps examined had mucus particles in their guts ( $\bar{x}$ of 4 branch tips \pm s.e. $=6$ polyps with mucus particles tip ${ }^{-1} \pm 1.35$ ) Forty-five min later $(1.0 \mathrm{~h}$ after initial exposure to food), there had been a $50 \%$ reduction in the number of polyps with mucus particles $\operatorname{tip}^{-1}$ (3.0 \pm 1.0 , $\bar{x} \pm$ s.e.) and in 3 to $4 \mathrm{~h}$ virtually all of the ingested mucus particles had been cleared from the polyp gut (Fig. 2).

The incorporation experiment, using radioactivelylabelled mucus, provides evidence for ingestion and incorporation of mucus particles. Living gorgonian

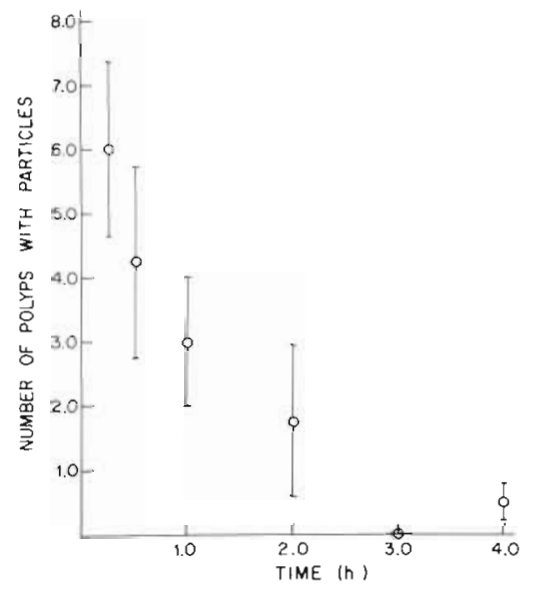

Fig. 2. Pseudoplexaura porosa. Digestion time course following clearance of labelled mucus particles from polyp guts. Twenty polyps tip ${ }^{-1}$ were examined and the number of polyps with mucus particles counted. Each point represents the mean of 4 branch tips. Bars: standard error

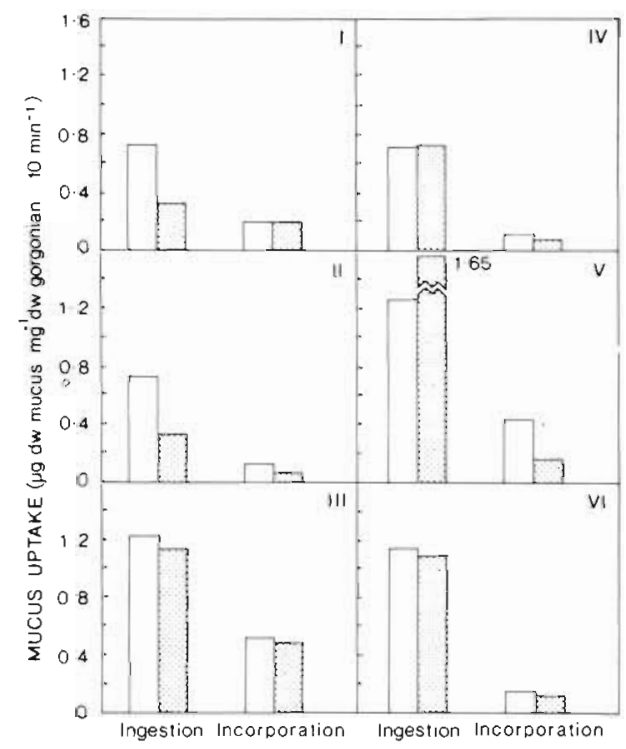

Fig. 3. Pseudoplexaura porosa. Chamber-by-chamber comparison of mucus ingestion and incorporation $(\mu \mathrm{g} \mathrm{dw}$ mucus $\mathrm{mg}^{-1} \mathrm{dw}$ gorgonian $10 \mathrm{~min}^{-1}$ ) by live branch tips (minus control adsorption) in the incorporation experiment. Difference in uptake between top ( $\square$ ) and middle ( $\bullet$ ) segments also illustrated. Each bar represents the mean of 2 replicate tips. Chamber numbers given in upper right corner of each box

branch tips showed a significant uptake in radioactivity $(\mathrm{P}<0.001,3$-way ANOVA, Table $1 ;$ Fig. 3$)$. In calculating mucus ingestion rates, adsorption of radioactive particles by dead controls was subtracted as a correction for surface adsorption of the label. Pseudoplexaura porosa ingested a mean of $0.91 \mu \mathrm{g} \mathrm{dw}$ mucus $\mathrm{mg}^{-1} \mathrm{dw}$ gorgonian after feeding on labelled mucus particles for $10 \mathrm{~min}$. After an additional $4 \mathrm{~h}$, $0.20 \mu \mathrm{g} \mathrm{dw}$ mucus $\mathrm{mg}^{-1} \mathrm{dw}$ gorgonian, or $22 \%$ of the mucus initially ingested, had been incorporated. 
Table 1. Pseudoplexaura porosa. Analysis of variance of data from the incorporation experiment. Live and control (dead) tips were considered as 2 treatments. Top segments and middle segments were analyzed as 2 positions

\begin{tabular}{|c|c|c|c|c|}
\hline \multicolumn{5}{|c|}{ Analysis of variance" } \\
\hline & $\mathrm{df}$ & $\begin{array}{l}\text { Mean } \\
\text { square }\end{array}$ & $F$ & $P$ \\
\hline \multicolumn{5}{|l|}{ Ingestion } \\
\hline \multicolumn{5}{|l|}{ Main effects } \\
\hline Chamber & 5 & 0.080 & 31.887 & $<0.001$ \\
\hline Position & 1 & 0.027 & 10.734 & 0.003 \\
\hline Treatment & 1 & 8.973 & 3587.172 & $<0.001$ \\
\hline \multicolumn{5}{|l|}{ Interactions } \\
\hline Chamber $\times$ Pos & 5 & 0.008 & 3.352 & 0.019 \\
\hline Chamber $\times$ Treat & 5 & 0.099 & 39.570 & $<0.001$ \\
\hline Treat $\times$ Pos & 1 & 0.032 & 12.597 & 0.002 \\
\hline Cham $\times$ Pos $\times$ Treat & 5 & 0.017 & 6.797 & $<0.001$ \\
\hline \multicolumn{5}{|l|}{ Incorporation } \\
\hline \multicolumn{5}{|l|}{ Main effects } \\
\hline Chamber & 5 & 0.295 & 11.557 & $<0.001$ \\
\hline Position & 1 & 0.020 & 3.925 & 0.059 \\
\hline Treatment & 1 & 1.324 & 259.118 & $<0.001$ \\
\hline \multicolumn{5}{|l|}{ Interactions } \\
\hline Chamber $\times$ Pos & 5 & 0.006 & 1.233 & 0.325 \\
\hline Chamber $\times$ Treat & 5 & 0.052 & 10.096 & $<0.001$ \\
\hline Pos $\times$ Treat & 1 & 0.028 & 5.418 & 0.029 \\
\hline Cham $\times$ Pos $\times$ Treat & 5 & 0.004 & 0.720 & 0.615 \\
\hline
\end{tabular}

In the incorporation experiment, significant differences in mucus ingestion occurred between the top and middle segments of the branch tip $(P=0.003$, 3-way ANOVA; Table 1). Significant differences between chambers as well as significant interactions among all 3 variables (chamber, treatment and position) were observed in this experiment (Table 1). This is probably a consequence of different individual uptake rates among feeding polyps on gorgonian branch tips since for both ingestion and incorporation, only a single live branch tip was taken from each chamber. For instance, a posteriori testing of the position effect in dead versus live branch tips demonstrated a significant position effect in the live branch tips $(P<0.05$, LSR posteriori test, Sokal and Rohlf, 1969), but none in the dead control branch tips (P>0.05, LSR).

In the ingestion experiment utilizing ${ }^{3} \mathrm{H}$-labelled bacteria attached to mucus particles Pseudoplexaura porosa ingested $0.62 \mu \mathrm{g} \mathrm{dw}$ mucus $\mathrm{mg}^{-1} \mathrm{dw}$ gorgonian $10 \mathrm{~min}^{-1}$ (controls subtracted to account for adsorption of label, Fig. 4). As in the incorporation experiment, uptake by polyps on the top segments of the branch tip was greater than uptake by the middle segments ( $P=$ 0.039 ; Table 2). There were no significant differences between chambers $(\mathrm{P}=0.36)$.

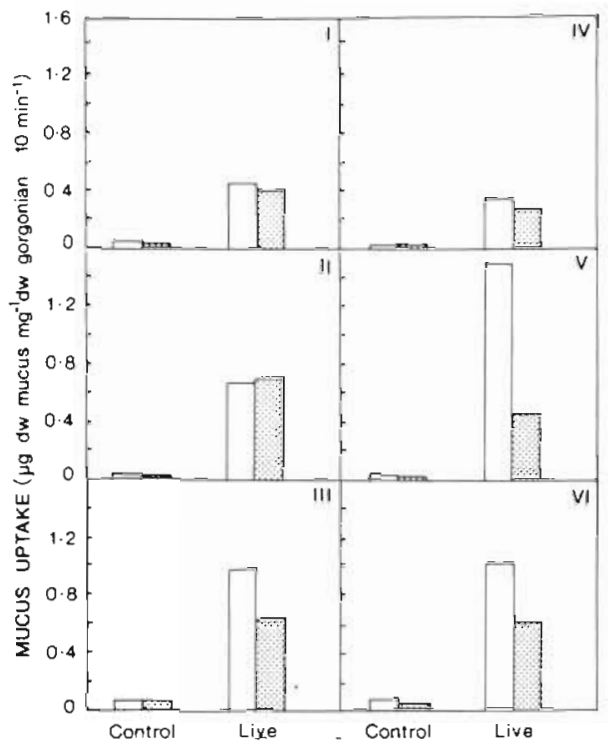

Fig. 4. Pseudoplexaura porosa. Chamber-by-chamber comparison of mucus uptake $\left(\mu \mathrm{g} d w\right.$ mucus $\mathrm{mg}^{-1} \mathrm{dw}$ gorgonian $10 \mathrm{~min}^{-1}$ ) by live and control branch tips in the ingestion experiment utilizing ${ }^{3} \mathrm{H}$-labelled bacteria attached to mucus particles. The difference in uptake between top ( $\square$ ) and middle (m) segments is also illustrated. Each bar represents the mean of 2 replicate tips. Chamber numbers given in upper right corner of each box

Table 2. Pseudoplexaura porosa. Analysis of variance of data from the ingestion experiment utilizing ${ }^{3} \mathrm{H}$-labelled bateria attached to mucus particles. Live and control (dead) branch tips were considered as 2 treatments. Top segments and middle segments were analyzed as 2 positions

\begin{tabular}{|c|c|c|c|c|}
\hline \multicolumn{5}{|c|}{ Analysis of variance ${ }^{*}$} \\
\hline & $\mathrm{df}$ & $\begin{array}{l}\text { Mean } \\
\text { square }\end{array}$ & $F$ & $P$ \\
\hline \multicolumn{5}{|l|}{ Main effects } \\
\hline Chamber & 5 & 0.446 & 1.151 & 0.360 \\
\hline Position & 1 & 1.916 & 4.728 & 0.039 \\
\hline Treatment & 1 & 118.785 & 293.183 & $<0.001$ \\
\hline \multicolumn{5}{|l|}{ Interactions } \\
\hline Chamber $\times$ Position & 5 & 0.476 & 1.176 & 0.349 \\
\hline Chamber $\times$ Treat & 5 & 0.303 & 0.748 & 0.595 \\
\hline Position $\times$ Treat & 1 & 0.006 & 0.014 & 0.907 \\
\hline
\end{tabular}

\section{DISCUSSION}

This study further characterizes particulate feeding in gorgonian soft corals. The octocoral Alcyonium digitatum can filter phytoplankton from water and other gorgonians can capture Artemia cysts, thus acting as particulate suspension feeders (Roushdy and Hansen, 1961; Lasker, 1981). In the present study the ability of gorgonians to act as particle feeders was 
again demonstrated. Gorgonians removed mucus particles from suspension and subsequently ingested and incorporated these particles.

The digestion time-course followed the extracellular removal of food from the polyp gut of Pseudoplexaura porosa. Virtually all of the food was removed after 3 to $4 \mathrm{~h}$, a result that is similar to those reported for other anthozoans (Boschma, 1925; Yonge and Nicholls, 1930; Porter, 1974). Murdock (1978a, b), investigating digestion and incorporation in 2 gorgonians, observed the digestion of radioactively-labelled mouse liver to be under way $1 \mathrm{~h}$ after ingestion and to be largely complete after $24 \mathrm{~h}$. Murdock's experiments followed protein digestion intracellularly and this probably accounts for the longer digestion times.

The 2 isotope-tracer techniques used to quantify ingestion of mucus particles yielded similar results, a significant increase in the radioactivity of feeding branch tips over non-feeding controls. There were no significant differences (2-level nested ANOVA; $\mathrm{P}>0.05 ; \mathrm{df}=1.10 ; \mathrm{f}=2.386$ ) in the ingestion rates as measured by the 2 techniques. Although the technique which provides a radioactively-labelled mucus substrate is preferred in most instances, the bacteriallabelling technique has the benefits of requiring shorter incubation times and smaller quantities of isotope. Measuring uptake with labelled bacteria attached to mucus particles does require several assumptions. The bacteria must be uniformly labelled and distributed on the mucus and must remain attached to the mucus particles for ingestion of label to measure ingestion of mucus. Mucus particles were rinsed with $250 \mathrm{ml} \mathrm{FSW}$ (10 $\times$ the volume of the mucus suspension) on a $3.0 \mu \mathrm{m}$ filter (Nucleopore) to remove unattached bacteria and any adsorbed label. Isotope lost to bacterial respiration and excretion can also bias measured uptake. To minimize lost due to exchange, mucus was used within $6 \mathrm{~h}$ of the specific activity determinations. Specific activities of water samples taken from the chambers were comparable with initial specific activities.

Mucus ingestion by the top segment (top $2 \mathrm{~cm}$ ) of the branch tip was greater than uptake by the middle segment (the next $2 \mathrm{~cm}$ ) in all of the experiments. This finding is not surprising given that settling particles strike the top segment first and that the top segment, with both tip and side surfaces, has more area for polyps. Differential feeding between segments may also be a consequence of clipping the tip from a colony and attaching the branch tip to the glass rod support. In several preliminary experiments the bottom $2 \mathrm{~cm}$ of $6 \mathrm{~cm}$ branch tips were analyzed and mucus ingestion was lower in this segment, than in the other 2 segments.

There are many corroborating reports of the presence of mucus aggregates in the field (Marshall, 1965.
1968; Johannes, 1967; Qasim and Sankaranarayanan, 1970; Coles and Strathmann, 1973; Marshall et al., 1975). This study indicates that Pseudoplexaura porosa can feed on mucus aggregates. Further work is necessary to determine if gorgonians feed on mucus particles in the field and to determine the trophic significance of this food resource for gorgonians. However, the nutritional value of mucus, the presence of mucus particles over the reef, and the ability of gorgonians to feed on these particles suggest that mucus particles can be an important food resource on reefs.

An estimate of the contribution which mucus can make to the nutrition of Pseudoplexaura porosa is calculated in Table 3 . In addition to the conversions

Table 3. Daily energy and carbon requirements of gorgonians met by incorporation of mucus particles

\begin{tabular}{|c|c|c|}
\hline & $\begin{array}{l}\mathrm{cal} \mathrm{g}^{-1} \\
\text { organic } \\
\text { matter }\end{array}$ & $\begin{array}{l}\mathrm{mg} \mathrm{C} \mathrm{g} \\
\text { organic } \\
\text { matter }\end{array}$ \\
\hline $\begin{array}{l}\text { Requirements } \\
\text { (Lewis and Post, 1982) }\end{array}$ & 39.2 & 3.7 \\
\hline $\begin{array}{l}\text { Mucus incorporation } \\
\text { (This study) }\end{array}$ & $109.6^{\circ}$ & $4.6^{\cdots}$ \\
\hline $\begin{array}{l}\text { Maximum \% of require- } \\
\text { ments potentially met } \\
\text { by feeding on mucus }\end{array}$ & $279 \%$ & $124 \%$ \\
\hline \multicolumn{3}{|c|}{$\begin{array}{l}\text { - Calculated using } 5.2 \mathrm{cal} \mathrm{mg}^{-1} \text { AFDW mucus (Richman } \\
\text { et al., 1975) } \\
\text { Porites mucus-70\% ash; P. porosa-59\% ash } \\
\text {. Calculated using } 0.065 \mathrm{mg} \mathrm{C} \mathrm{dw}^{-1} \text { mucus (Gottfried } \\
\text { and Roman, 1983) }\end{array}$} \\
\hline
\end{tabular}

used in the calculation the estimate also assumes that ingestion rates observed in this study may be extrapolated to colonies in the field. First, branch tips used in the experiments behaved similary to entire colonies and ingestion rates using different techniques did not differ significantly. Second, although densities of mucus aggregates in reef waters have not been measured to date, the concentrations of mucus particles used in this study (9.2 to $14.6 \mathrm{mg} \mathrm{l}^{-1}$ ) were within the range of the total particulate matter concentrations in reef waters where this work was conducted (4.3 to $15.0 \mathrm{mg} \mathrm{l}^{-1}$; Gottfried and Roman, 1983). The availability of mucus particles in the field is probably lower than the concentrations used in the experiments. Therefore, the values in Table 3 should be interpreted as an upper bound of the energy derived from mucus. The calculations suggest that $P$. porosa can theoretically incorporate sufficient mucus to meet the energetic and carbon requirements of the colony's respiration. The values do not imply that mucus particles are satisfying all of the 
nutritional needs of the gorgonian in the reef environment, but the results do indicate that $P$. porosa is able to incorporate a natural food source that could provide a significant contribution to its diet.

Many workers have postulated a trophic role for mucus and report its presence in the reef environment (e.g. Johannes, 1967; Coles and Strathmann, 1973; Benson and Muscatine, 1974). Mucus aggregates are recognized as one route by which the energy-rich products of coral metabolism are transferred to higher trophic levels' (Lewis, 1977; see also Coles and Strathmann, 1973; Benson and Muscatine, 1974; Ducklow and Mitchell, 1979). This study (like those of Richman et al., 1975 and Gottfried and Roman, 1983) is a first step towards demonstrating this transfer.

Acknowledgements. I thank M. D. Gottfried and S. M. Markley for assistance in this study and H. R. Lasker, M. R. Roman and $W$. S. Clayton as well as several anonymous reviewers for critical comments on the manuscript. I thank Klaus Rützler and the Smithsonian Coral Reef Project for space and facilities at Carrie Bow Cay, Belize. This research was supported in part by National Science Foundation Grant No.: OCE 78-26084 to M. R. Roman and a Maytag fellowship to the author. This research was done in partial fulfillment for a M. S. degree from the University of Miami.

\section{LITERATURE CITED}

Benson, A. A., Muscatine, L. (1974). Wax in coral mucus: energy transfer from corals to reef fish. Limnol. Oceanogr. 19: $810-814$

Boschma, H. (1925). On the feeding reactions and digestion in the coral polyp Astrangia dande, with notes on its symbiosis with zooxanthellae. Biol. Bull. mar. biol. Lab., Woods Hole 49: 407-439

Coles, S. L., Strathmann, R. (1973). Observations on coral mucus flocs and their potential trophic significance. Limnol. Oceanogr. 18: 673-678

Daumas, R., Thomassin, B. A. (1977). Protein fractions in coral and zoantharian mucus: possible evolution in coral reef environments. In: Taylor, D. L. (ed.) Proc. 3rd int. Symp. coral reefs, Vol 1. University of Miami, Miami, p. 517-523

Ducklow, H. W., Mitchell, R. (1979). Composition of mucus released by coral reef coelenterates. Limnol. Oceanogr. 24: 706-714

Fleming, J. M., Coughlan, J. (1978). Preservation with vitally stained zooplankton for live/dead sorting. Estuaries 1: $135-137$

Goreau, T F., Goreau, N. I., Yonge, C. M., Neuman, Y. (1970). On feeding and nutrition in Fungiacava eilatensis (Bivalvia, Mytilidae), a commensal living in fungiid corals. J. Zool. Lond. 160: 159-172

Gottfried, M. D., Roman, M. R. (1983). The ingestion and incorporation of coral mucus detritus by reef zooplankton. Mar. Biol. 72: 211-218

Gust, G. (1977). Turbulence and waves inside flexible-walled systems designed for biological studies. Mar. Biol. 42: $47-53$

Johannes, R. E. (1967). Ecology of organic aggregates in the vicinity of a coral reef. Limnol. Oceanogr. 12: 189-195
Kinzie, R. A. (1970). The ecology of the gorgonians (Cnidaria, Octocorallia) of Discovery Bay, Jamaica. Ph. D. thesis, Yale University

Lasker, H. R. (1981). A comparison of the particulate feeding abilities of three species of gorgonian soft coral. Mar. Ecol. Prog. Ser. 5: 61-67

Lasker, H. R., Gottfried, M. D., Coffroth, M. A. (1983). The effects of depth on the feeding capabilities of two octocorals. Mar. Biol. 73: 73-78

Lewis, D. H., Smith, D. C. (1971). The autotrophic nutrition of symbiotic marine coelenterates with special reference to hermatypic corals. 1. Movement of photosynthetic products between symbionts. Proc. R. Soc. Lond. (B) 178: $111-129$

Lewis, J. B. (1973). The formation of mucus envelopes by hermatypic corals of the genus Porites. Carib. J. Sci. 13: $207-209$

Lewis, J. B. (1977). Processes of organic production on coral reefs. Biol. Rev. 52: 305-347

Lewis, J. B., Post, E. E. (1982). Respiration and energetics in West Indian Gorgonacea (Anthozoa, Octocorallia). Comp. Biochem. Physiol. 71A: 457-459

Mariscal, R. N., Bigger, C. H. (1977). Possible ecological significance of octocoral epithelial ultrastructure. In: Taylor, D. L. (ed.) Proc. 3rd int. Symp. coral reefs, Vol. 1. University of Miami, Miami, p. 127-133

Marshall, N. (1965). Detritus over the reef and its potential contribution to adjacent waters of Eniwetok Atoll. Ecology 46: $343-344$

Marshall, N. (1968). Observations on organic aggregates in the vicinity of coral reefs. Mar. Biol. 2: 50-53

Marshall, N. (1969). Notes on mucus and zooxanthellae discharged from reef corals. In: Mukundan, C., GopinadhaPillai, C. S. (ed.) Proc. Symp. Corals and Coral Reefs. Mar. biol. Ass. India, p. 59-65

Marshall, N., Durbin, A. G., Gerber, R., Telek, G. (1975). Observations on particulate and dissolved organic matter in coral reef areas. Int. Revue ges. Hydrobiol. 60: 335-345

Murdock, G. R. (1978a). Digestion, assimilation and transport of food in the gastrovascular cavity of a gorgonian octocoral (Cnidaria: Anthozoa). Bull. mar. Sci. 28: 354-362

Murdock, G. R. (1978b). Circulation and digestion of food in the gastrovascular system of gorgonian octocoral (Cnidaria: Anthozoa). Bull. mar. Sci. 28: 363-370

Patton, J. S., Battey, J. F., Rigler, M. W., Porter, J. W., Black, C. C., Burris, J. E. (1983). A comparison of the metabolism of bicarbonate ${ }^{14} \mathrm{C}$ and acetate $1-{ }^{14} \mathrm{C}$ and the variability of species lipid compositions in reef corals. Mar. Biol. 75: 121-130

Porter, J. W. (1974). Zooplankton feeding by the Caribbean reef-building coral Montastrea cavernosa. In: Great Barrier Reef Committee (ed.) Proc. 2nd int. Symp. coral reef. Vol. 1. Brisbane, Australia, p. 111-125

Qasim, S. A., Sankaranarayanan, V. N. (1970). Production of particulate matter by the reef on Kavaratti Atoll (Laccadives). Limnol. Oceanogr. 15: 574-578

Richman, S., Loya, Y., Slobodkin, L. B. (1975). The rate of mucus production by corals and its assimilation by the coral reef copepod Acartia negligens. Limnol. Oceanogr. 20: 918-923

Roushdy, H. M., Hansen, V. K. (1961). Filtration of phytoplankton by the octocoral Alcyonium digitatum L. Nature, Lond. 190: 649-650

Rublee, P. A., Lasker, H. R., Gottfried, M., Roman, M. R. (1980). Production and bacterial colonization of mucus from the soft coral Briarium asbestinum. Bull. mar. Sci. 30: 888-893 
Sokal, R., Rohlf, F. J. (1969). Biometry. W. H. Freeman, San Francisco

Stephens, G. C. (1962). Uptake of organic material by aquatic invertebrates I. Uptake of glucose by the solitary coral Fungia scutaria. Biol. Bull. mar. biol. Lab., Woods Hole 123: 648-659
Yonge, C. M., Nicholls, A. G. (1930). Studies on the physiology of corals. II. Digestive enzymes with notes on the speed of digestion. Grt. Br Reef Exped., 1928-1929, Sci. Repts 1: 15-57

This paper was presented by Professor K. R. Tenore; it was accepted for printing on February 1, 1984 